\title{
METFORMIN FOR PREVENTION AND TREATMENT OF PREECLAMPSIA: POSSIBLE MECHANISMS AND FUTURE RESEARCHES
}

\author{
Hamidreza Samimagham ${ }^{1}$, Negar Askari ${ }^{2}$, Hamidreza Mahboobi ${ }^{3}$
}

1: M.D., Associate Professor, Nephrologist, Shahid Mohammadi clinical research development center, Hormozgan University of Medical Sciences, Bandar Abbas, Iran

2: M.D., Obstetrics and Gynecologist, Mother and Child Welfare Research Center, Hormozgan University of Medical Sciences, Bandar Abbas, Iran.

3: M.D., Resident of Internal medicine, Infectious and Tropical Diseases Research Center, Hormozgan Health Institute, Hormozgan University of Medical Sciences, Bandar Abbas, Iran

\section{TYPE OF ARTICLE: LETTER TO EDITOR}

\section{Dear Editor,}

Gestational diabetes mellitus (GDM) and preeclampsia are two common complications of pregnancy. Their prevention and treatment are interesting issues in the field of obstetrics. Both of these conditions are associated with a high risk of pregnancy complications. Metformin is an oral hypoglycemic agent which is shown to be effective in management of GDM $(1,2)$. Although several years ago, metformin had no role in management of GDM because of uncertainties about the possibility of fetal side effects, recently increasing evidence is reported about its safety in pregnancy and also its effectiveness in management of GDM $(3,4)$. Metformin had been used in patients with polycystic ovarian syndrome (5-7), then its use was developed to patients with GDM. A recent paper has reported its role in decreasing weight gain in obese pregnant women without diabetes mellitus (8). In this paper, the authors highlighted the role of metformin in decreasing the rate of preeclampsia (8). However, similar results are reported by other researchers, but current available evidence is conflicting $(1,9)$.

In a recent paper, Brownfoot et al. highlighted the role of metformin in prevention and treatment of preeclampsia (10) and some possible mechanisms of the role of metformin in preeclampsia. Results of this study showed reduction of soluble fms-like tyrosine kinase 1 and soluble endoglin secretion by metformin, from endothelial and placental tissues. These mechanisms are involved in the process of preeclampsia, and metformin had the potential for treatment and prevention of preeclampsia by the mentioned mechanisms (10). Some other mechanisms are believed to play a preventive role of metformin in preeclampsia. Decreased expression of vascular cell adhesion molecule 1 (VCAM-1) in endothelial cells are another mechanism of prevention of preeclampsia. Vascular cells and angiogenesis are other important factors in pathophysiology of preeclampsia. Metformin improves angiogenesis and vasodilation of omentum vessels (10).

We recommend randomized controlled trials on the role of metformin in preeclampsia. Metformin side effects, including lactic acidosis, which affect both mother and fetus, should be carefully monitored. The rate of lactic acidosis is low in patients using metformin, and this condition is reported in patients using doses higher than 3 gr per day of metformin. In patients with hepatic impairment, it should be used cautiously, because renal impairment is a risk factor for lactic acidosis.

\section{CONFLICT OF INTEREST:}

There is no conflict of interest to be declared.

\section{Correspondence:}

Dr. Hamidreza Mahboobi, Infectious and Tropical Diseases Research Center, Hormozgan Health Institute, Hormozgan University of Medical Sciences, Bandar Abbas, Iran, Tel: +98. 9172121995, Email: hamidrezamahboobi@yahoo.com

Received: June 29, 2016, Accepted: August 3, 2016, Published: September 2016 iThenticate screening: July 1, 2016, English editing: August 16, 2016, Quality control: August 23, 2016

(c) 2016 The Authors. This is an open access article under the terms of the Creative Commons Attribution-NonCommercialNoDerivs License, which permits use and distribution in any medium, provided the original work is properly cited, the use is non-commercial and no modifications or adaptations are made. 


\section{REFERENCES:}

1) Zhu B, Zhang L, Fan YY, Wang L, Li XG, Liu T, et al. Metformin versus insulin in gestational diabetes mellitus: a meta-analysis of randomized clinical trials. Irish Journal of Medical Science. 2016; 185(2): 37181. doi: 10.1007/s11845-016-1414-x. PMid: 26860118.

2) Ainuddin J, Karim N, Hasan AA, Naqvi SA. Metformin versus insulin treatment in gestational diabetes in pregnancy in a developing country: a randomized control trial. Diabetes Research and Clinical Practice. 2015; 107(2): 290-9. doi: 10.1016/j.diabres.2014.10.001. PMid: 25467617.

3) Li G, Zhao S, Cui S, Li L, Xu Y, Li Y. Effect comparison of metformin with insulin treatment for gestational diabetes: a meta-analysis based on RCTs. Archives of Gynecology and Obstetrics. 2015; 292(1): 111-20. doi: 10.1007/s00404-014-3566-0. PMid: 25547060.

4) Marques P, Carvalho MR, Pinto L, Guerra S. Metformin safety in the management of gestational diabetes. Endocrine Practice. 2014; 20(10): 1022-31. doi: 10.4158/EP14018.OR. PMid: 24793923.

5) Feng L, Lin XF, Wan ZH, Hu D, Du YK. Efficacy of metformin on pregnancy complications in women with polycystic ovary syndrome: a meta-analysis. Gynecological Endocrinology. 2015; 31(11): 833-9. doi : 10.3109/09513590.2015.1041906. PMid: 26440203.

6) Zheng J, Shan PF, Gu W. The efficacy of metformin in pregnant women with polycystic ovary syndrome: a meta-analysis of clinical trials. Journal of Endocrinological Investigation. 2013. 36(10): 797-802. doi: 10.3275/8932. PMid: 23580001.

7) Vanky E, Stridsklev S, Heimstad R, Romundstad P, Skogoy K, Kleggetveit O, et al. Metformin versus placebo from first trimester to delivery in polycystic ovary syndrome: a randomized, controlled multicenter study. The Journal of Clinical Endocrinology \& Metabolism. 2010; 95(12): E448-55. doi: 10.1210/jc.20100853. PMid: 20926533.

8) Syngelaki A, Nicolaides KH, Balani J, Hyer S, Akolekar R, Kotecha R, et al. Metformin versus Placebo in Obese Pregnant Women without Diabetes Mellitus. New England Journal of Medicine. 2016; 374(5): 43443. doi: 10.1056/NEJMoa1509819. PMid: 26840133.

9) Tan X, Li S, Chang Y, Fang C, Liu H, Zhang X, et al. Effect of metformin treatment during pregnancy on women with PCOS: a systematic review and meta-analysis. Clinical \& Investigative Medicine. 2016; 39(4): E120-31. PMid: 27619399.

10) Brownfoot FC, Hastie R, Hannan NJ, Cannon P, Tuohey L, Parry LJ, et al. Metformin as a prevention and treatment for preeclampsia: effects on soluble fms-like tyrosine kinase 1 and soluble endoglin secretion and endothelial dysfunction. American Journal of Obstetrics \& Gynecology. 2016; 214(3): 356e1-e15. doi: 10.1016/j.ajog.2015.12.019. PMid: 26721779. 